Perhaps the most encouraging feature of the memorandum is the evidence it provides that the Institute of Political and Social Studies has clear ideas as to what is needed, in respect of the conditions on which effective research depends, of the organization of research, and of the qualities required in its direction. Dr. Mendelssohn's broadcast talk supplies evidence that there are other Indian sources also competent to give the Review Committee all the guidance it should need as to the organization of the National Research Laboratories. A.t the outset, however, he makes it only too apparent that the causes run deep and that there is widespread frustration and discontent in universities as well as in Government research laboratories, largely but not wholly due to the effect of the 20 per cent cut in their budgets imposed as an emergency measure in 1963 . Since the director could not dismiss his staff and their salaries had to be paid, this involved a reduction of 60-70 per cent in running expenses.

Dr. Mendelssohn picks out the quality of scientific publication, and the reluctance of Indian scientists to return to India after training in the West, as evidence that all is not well with science and technology in India. His observations satisfied him that there was justification in some of the reasons given for this reluctance-in the lack of appreciation, insufficient means for research, difficulties in obtaining equipment, pettiness and jealousy among colleagues. It seems only too clear that Dr. Dedijer's plea for a clearer understanding of science and its implications and for the formulation of scientific policy, addressed more particularly to the emerging nations, applies no less to India. Too many of her politicians, as Dr. Mendelssohn recognizes, are not science-minded, and the trouble starts in the universities, modelled on Western institutions of the pre-scientific era.
While it is true that the whole purpose of the Commonwealth Scholarship and Fellowship Plan will be defeated if many of the Scholars and Fellows do not return to their own country when tenure of their scholarship and fellowship expires, it must not be forgotten that this is largely a matter for the country which sends the scholars and Fellows. Fortunately, as Dr. Mendelssohn shows, there are hopeful signs. India, he recognizes, has scientists who are second to none. $\mathrm{H}_{e}$ is impressed by her reserve of capable brains and by the younger generation of scientists whose love for their subject is matched by their capacity for hard work, and often by their competence. Moreover, there are, here and there, as at the Tata Institute in Bombay and the Atomic Energy Research Laboratories at Trombay, those who have the strength of character to oppose the Government, and he does not despair of the real impetus coming, as it must, from India itself.

What is needed is to create the conditions in which the young generation of Indian scientists can develop their talents and work for their country, and what Indian professors and directors of research need is the art of talking to their own Government. These are the two key conditions which will determine the readiness of Indian scholars abroad to return to their country. This should be remembered both in discussing the future of the Commonwealth Scholarship and Fellowship Plan, and in assessing the extent and character of the technical assistance given to India. With sympathy and insight much could be done indirectly, rather than by direct action, to help Indian politicians to understand the situation and to appreciate the nature of the action required, if not merely India's science but her general economic and social development are to proceed on the scale and at the rate which has been planned.

\title{
MARINE RESEARCH AT ZANZIBAR
}

\begin{abstract}
$\mathrm{N}$ important aspect of the International Indian Ocean A Expedition has been the part played by the various marine research stations in the area. Not only have they offered facilities for research vessels and made their own individual contributions to the Expedition, but, perhaps more important, their previous research activities have provided much valuable information on which the assault on the Indian Ocean could be planned. The research station at Zanzibar, although hampered during much of 1963 by the absence of its research vessel, R.V. Manihine (for refit and survey), nevertheless continued some promising lines of research and initiated some new ones*. Three new biologists were recruited during 1963, bringing the scientific complement up to four research officers in addition to the director.
\end{abstract}

In the absence of the R.V. Manihine, the deep longline investigation, work on demersal fishes, and hydrological work had to be abandoned. On the other hand, a new vessel, the 58. ft. Jodari, built by and for the use of the Government-sponsored Zanzibar Fisheries Development Co., Ltd., and the purchase of a $450 \times 45 \mathrm{fm}$. purse-seine net, enabled investigations to be made of day-time fishing for scombroid fishes. Of the latter, five types of shoal have been distinguished on their species composition, the majority of shoals containing honito and frigate mackerel in the proportions of $50: 50$ to $97: 3$. The food of the tuna examined consisted chiefly of small fishes (Stolephorus and Atherina) with occasional small crustaceans and cephalopods.

Two further boats were operated by the Zanzibar Fisheries Development Co. (39 ft. and $55 \mathrm{ft}$.), both used

* East African Common Services Organization. Annual Report of the East African Marine Fisheries Research Organization for 1963. Pp. iv +19 . in night purse-seining for sardine-like fishes. As elsewhere, night fishing with lights was limited to about twenty days between full moons. Initial difficulties were encountered in finding areas free from coral. Of the clupeid species, Sardinella jussieu (Lacépède), S. perforata (Cantor) and S. sirm (Walbaum) (the latter an offshore species) were the most abundant, but several small carangids were commonly caught (for example, Decapterus dayi Wakiya). The purse-seines also took significant numbers of tuna-like fishes. Highest landings were recorded during the periods May-July and November-. December.

Prawns collected during three cruises off the Tanganyika coast, supplemented by specimens from elsewhere in the Indo-Pacific Ocean, were reported on at the meeting of carcinologists at Zanzibar, organized by the Scientific Council of the Commission for Technical Co-operation in Africa South of the Sahara in April. Three useful papers on plankton were published during 1963, resulting from collections made in the Zanzibar area during 1960-61; one strongly denies the popular conception of the 'impoverishment of tropical seas'.

Interest in the work of the Zanzibar station is evidenced by the amount of financial assistance received from outside sources: Unesco for library material; the Rockefeller Foundation for hydrological equipment; the Food and Agriculture Organization for deep long-line gear; the Freedom from Hunger Campaign for purse-seine net; the Munitalp Foundation for hydrographic winch, etc. It is to be hoped that the valuable contributions made by Zanzibar to knowledge of the Indian Ocean and its fisheries will continue to be recognized.

P. J. P. Whitehead 